\title{
Appraisal of Corporate Social Responsibility Practices of Selected Medium Size Contracting Firms in South-South Nigeria
}

\author{
Olatunde N. A. and Okorie V. N
}

\begin{abstract}
Construction project abandonment, delay in completion time, huge variation between contract sum and final account figure, etc. is gradually becoming a norm in the South-South region of Nigeria compared to other regions. These anomalies have been linked to consequential effect of communal agitations resulting from economic, political and environmental neglect. This study therefore seeks to appraise the corporate social responsibility (CSR) practices of medium size contracting firms in the zone with a view to explore the relationship between CSR practices and project delivery in the region. Purposive sampling technique was used to select 12 contracting firms operating within the region for 10 years (2008-2017). Structured questionnaire was used to obtain quantitative data used for the study. Data analysis was carried out using percentile, frequency, mean item score and correlation analysis. The findings revealed that $27.5 \%$ of the contracting firms have CSR policy, $17.5 \%$ of the firms have CSR as core mandate in their company vision statement. Importantly, the finding also revealed that most of the contracting firms within the region incorporate local content policy of employing indigenes of the host community (MIS=3.73) as their most important CSR practice. The study recommends that there should be an enactment and enforcement of enabling laws that make it compulsory for business owners to have CSR policy and entrench CSR as a core mandate in their vision statement as a criterion for business registration for all categories of construction companies in Nigeria.
\end{abstract}

Keywords: Corporate social responsibility, practices, insecurity, South-South, Nigeria

\section{Introduction}

The South-South zone of Nigeria in the recent years has been notorious for militancy, kidnapping, civil unrest [1] and work disruption [2] due to agitations against socialeconomic neglects and environmental pollution. [3] noted that most of the communal agitations were triggered off by neglect in provision of social amenities by some of the construction companies operating within the region, resulting in construction projects abandonment, unpredictability of completion time and construction cost overruns. In

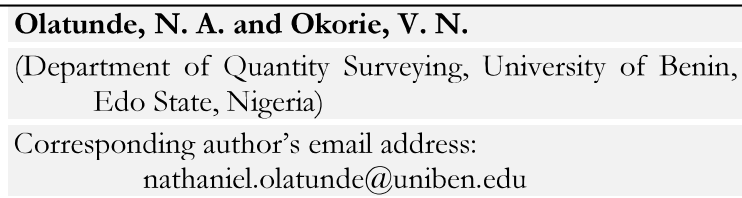

addition to lack of social amenities, [1] noted that there are also serious cases of environmental pollution resulting from oil and gas exploration within the region.

However, the wellbeing of people has been a concern to the World body such as European Union (EU) Treaty. The EU Treaty encourages corporate entities through her advocacy to incorporate social and environmental issues into their company's portfolio. The treaty further states that it is an obligatory for companies like construction firms, oil and gas companies dealing with hazardous substances to incorporate CSR as a core business value. This noble policy by the EU was corroborated by [4] who stated that corporate entities cannot thrive well without given parts of their profits to her host communities. For instance, host 
community needs social-economic development from the company while the company needs security, mutual co-existence and profits maximization to keep the organization going.

In the western nations and other developed countries, CSR is an integral part of business core values. Perhaps in Nigeria context, the CSR has been regarded as a philanthropy gesture to the host community by the operating companies. Nonetheless, Nigerian indigenous firms regard CSR as a philanthropy gesture that a company may or may not give to her host [4]. Then again, the practices of CSR vary not only across nations but also among companies [5].

However, [4] noted that CSR practices in Nigeria are still very low. Nonetheless, CSR has enormous social-economic benefits to both the host communities and companies alike and should be incorporated into Nigerian business environments [6]. However, there are divergence of opinions among scholars and researchers on CSR. For instance, [7] see CSR as a philanthropy gesture by the operating company to improve social-economic and infrastructural facilities within their host communities while [8] cited in [7] did not support the principle of CSR, rather see company as wealth maximization for the shareholders. [9] expressing the view of the World Bank in respect of organizations and CSR, stated that registered corporate entity has an obligation to set aside $5-10 \%$ of annual profit for social-economic and environmental issues to the host community. This could come in the form of scholarships for the children and wards of host community and provision of infrastructural facilities such as roads, electricity, and town halls.
[10] holds the view that CSR is legal right to the host communities who are directly affected by the activities of the companies. We live a mutual world; therefore, business entities should go beyond its normal profit maximization motives and provide some basic social-economic amenities to their host communities [11]. In any business environment, where security of lives and properties are granted, there will be both tangible and intangible benefits accruing to the companies and the host communities. Tangible benefits include: higher productivity and profits to the operating companies, while intangible benefits such as social harmony existing between the host community and the company give room to prosperity and environmental sustainability.

Researches in the recent years mostly in the developed countries have examined the applicability of stakeholder theory relative to CSR of construction companies ([12]- [17]. In Nigeria, however, there are few researches on CSR practices among construction companies especially in the South-South zone. Some of the few earlier studies on the CSR in the Nigeria include [18] who appraised the CSR as a driver within construction organization in Nigeria; [19] examined CSR and financial performance in the Nigerian construction industry and [4] explores Nigerian indigenous firms and CSR practices. There is need to fill in this gap by appraising the CSR practices of medium size contracting firms in the SouthSouth Nigeria. The aim of the study was to appraise the CSR practices of medium size contracting firm in the South-South zone of Nigeria with a view to draw relationship between CSR practices and project delivery in the zone. The specific objectives included: appraise the extent of CSR practices in the 
study area; determine whether there is significant relationship between CSR practice and frequency of work stoppage due to community agitation and to determine whether there is significant relationship between CSR practice and work stoppage due to insecurity in the region.

To achieve these objectives, the following hypotheses were formulated:

Ho1. There is no significant relationship between the extent of CSR practice and frequency of work stoppage due to community agitation in the study area;

Ho2. There is no significant relationship between the extent of CSR practice and frequency of work stoppage due to insecurity in the study area.

\section{Literature Review}

CSR has different meanings according to different scholars, but the one that has stood the test of time is from [20] cited in [21] that entails social-economic, legal, ethical, and philanthropic expectations placed on companies by the society or host communities. Indisputably, CSR according to [20] emphasized the obvious that there are some social-economic expectations the host community placed on every business organization operating within a given environment to respond for the mutual benefits of both [22]. [23] affirmed that organizations should put CSR consideration as a core business value and respond positively if they want to earn the 'respect of society' and make higher profit.

The European Union sees CSR as socialeconomic and environmental issues that every corporate entity should entrenched into their business portfolio for better interaction with the host communities [24]. However, CSR of an organization to her host communities varies from organization to organization. [25] posited that CSR connotes social-economic responsibilities an organization owns her host communities for mutual co-existence. For example, provision of electricity, roads, water, protection to public health, public safety, and environmental sustainability will be beneficial to both.

According to [26] CSR is one of the management policies undertaken by top management of an organization to provide information on social-economic and environmental issues as it relates to the environment. [27] viewed CSR as a means by which the top management of organizations can interact with the broader society for mutual benefits and co-existence. Indisputably, CSR has unquantifiable benefits to both the operating companies and host communities. Interestingly, the findings of [14] who examined the extent to which CSR was entrenched into corporate governance structure of companies operating in the Netherlands showed that CSR of multinationals companies performance credibly well in terms of provision of social amenities to their host communities.

Regrettably, CSR practices in Nigeria, particularly among the indigenous firms are very low. [28] found that the CSR practices by the oil and gas companies in the Niger Delta is inadequate and not meeting the desired goal on the host communities. In the same vein, [29] appraised the styles of CSR practices of some companies in Nigeria and found that CSR is more of public relations machinery than a tool for socio-economic development. However, 
the study by [30] on the nature and practice of corporate social responsibility of Julius Berger Nigeria PLC in the Federal Capital Territory (FCT) indicated that the degree of the company's actual participation in CSR practices on its host communities is average. Then again, the efforts of governments at all levels and the civil society are highly required to encourage companies in respective of their size to actively participate in CSR practices in their host communities.

\section{A. Materials and Methods}

Purposive sampling technique was used to select twelve medium size contracting firms for the study. The names of the firms were deliberately not released for publication so as to ensure secrecy as a result of privacy agreement entered with the respondents so as to guarantee release of data. The three major criteria for selection were that; the company must have registered with Federal Ministry of Works as class B category of contracting organization, the company must have executed construction project in at least three States in the study area (South-South) within the last ten years (2008-2017) and that the contract sum of none of the project executed in the zone was less than one hundred million Naira. The choice of ten-year period was to be sure that the companies have worked within the zone for a reasonably long time and thereby have sufficient experience to justify their selection. Questionnaire survey was administered to four senior management staff (Chief Accountant, Chief Quantity Surveyor, Human Resource Manager and Lead Project Manager of the selected companies for data analysis. The questionnaire designed for data collection was divided into two sections. The first section deals with the background information of the respondent, while the second section deals with specific questions relating to the objectives of the study. Descriptive data analysis was employed using frequency, percentile and mean Item Score (MIS) and inferential analysis was carried out by correlation analysis.

\section{B. Results and Discussion}

Table 1 shows the summary of the characteristics of the respondents to the questionnaire. The result indicated that 40 $(83.33 \%)$ questionnaires were retrieved from the respondents out of the 48 sent out. The $83.33 \%$ return rate was considered adequate for the survey considering the submission of [31] that the result of a survey could be considered as biased and of little significant if the return rate was lower than $20-30 \%$. The professions of the respondents cut across all the target population that could have adequate information regarding CSR practices of their organization. Majority $(27.5 \%)$ of the respondents were project managers, $20.0 \%$ each were Chief Accountants and Chief Quantity Surveyors, $17.5 \%$ were Chief Architects and only $15.0 \%$ were Human Resources Managers. Majority of the respondents $(70.0 \%)$ have worked with their organization for 11years and above. This shows that they have been with the company for sufficient length of time to have adequate information about the company. The academic background of the respondents was considered adequate as $40.0 \%$ of them were holders of master's degrees, $30.0 \%$ hold PGD certificate, $27.5 \%$ hold bachelor degree and only $2.5 \%$ hold Higher National Diploma (HND). All the respondents were members of their various professional bodies. While 62.5\% were 
associate members, $37.5 \%$ were fellows of their professional bodies. The background information of the respondents indicated that they were adequately qualified to give required information and could be relied on.

The information on Table 2 indicates respondents' perceptions on whether their companies have CSR policy in place. Majority of the respondents $(65.0 \%)$ indicated that their company does not have CSR policy in place, while only minority $(27.5 \%)$ indicated that they have CSR policy in their company. However, $7.5 \%$ of the respondent indicated that they were not sure whether the company has CSR policy or not. From this result it could be inferred that lack of CSR policy in majority of the construction companies undertaken construction work in the study area could be

Table 1: Summary of respondents' characteristics

\begin{tabular}{|c|c|c|c|}
\hline Category & Classification & Frequency & Percentage \\
\hline \multirow{7}{*}{$\begin{array}{l}\text { Profession of } \\
\text { respondent }\end{array}$} & Quantity surveyor & 9 & 22.5 \\
\hline & Architect & 6 & 15.0 \\
\hline & Builder & 1 & 2.5 \\
\hline & Project manager & 9 & 22.5 \\
\hline & Accountant & 8 & 20.0 \\
\hline & Others & 7 & 17.5 \\
\hline & Total & 40 & 100.0 \\
\hline \multirow{6}{*}{$\begin{array}{l}\text { Designation } \\
\text { of } \\
\text { respondent }\end{array}$} & Chief architect & 7 & 17.5 \\
\hline & Chief Accountant & 8 & 20.0 \\
\hline & Chief Quantity surveyor & 8 & 20.0 \\
\hline & $\begin{array}{l}\text { Human resource } \\
\text { manager }\end{array}$ & 6 & 15.0 \\
\hline & Project manager & 11 & 27.5 \\
\hline & Total & 40 & 100.0 \\
\hline \multirow{6}{*}{$\begin{array}{l}\text { Length of } \\
\text { time of } \\
\text { working the } \\
\text { company }\end{array}$} & $1-5$ & 5 & 12.5 \\
\hline & $6-10$ & 7 & 17.5 \\
\hline & $11-15$ & 9 & 22.5 \\
\hline & $16-20$ & 10 & 25.0 \\
\hline & Above 20 & 9 & 22.5 \\
\hline & Total & 40 & 100.0 \\
\hline \multirow{7}{*}{$\begin{array}{l}\text { Highest } \\
\text { academic } \\
\text { qualification }\end{array}$} & HND & 1 & 2.5 \\
\hline & PGD & 12 & 30.0 \\
\hline & Bachelor & 11 & 27.5 \\
\hline & Masters & 16 & 40.0 \\
\hline & Total & 40 & 100.0 \\
\hline & NIQS & 8 & 20.0 \\
\hline & NIA & 8 & 20.0 \\
\hline \multirow{4}{*}{$\begin{array}{l}\text { Membership } \\
\text { of } \\
\text { professional } \\
\text { bodies }\end{array}$} & NIOB & 3 & 7.5 \\
\hline & PMI & 7 & 17.5 \\
\hline & ICAN & 8 & 20.0 \\
\hline & Others & 6 & 15.0 \\
\hline \multirow{3}{*}{$\begin{array}{l}\text { Type of } \\
\text { membership }\end{array}$} & Associate & 25 & 62.5 \\
\hline & Fellow & 15 & 37.5 \\
\hline & Total & 40 & 100.0 \\
\hline
\end{tabular}

responsible for absence of harmonious work relationship between construction companies in the study area and the host communities which often resulted in higher construction cost, kidnapping of key staffs of some construction companies, delay in completion or total project abandonment.

The result of the responses from the respondents on whether CSR was mentioned as a core mandate in their company was shown in Table 3. The result shows that only $17.5 \%$ of the respondents indicated that CSR was mentioned as core mandate in their companies. On the contrary, $77.5 \%$ of the respondents stated that CSR was not mentioned as a core mandate in their company vision statement. While $5.0 \%$ of the respondents were not sure if CSR was mentioned as core mandate in their company vision statement. The inference that could be drawn from this result was that majority of medium size construction companies executing works within the SouthSouth region of Nigeria do not have CSR as one of their core mandates, consequently there will be little or no CSR practice within the zone. The lack therefore could continue to have negative impact on the host communities. Thus, there will be continuous community agitations, insecurity and kidnapping within the region due to neglect in provision of socialeconomic amenities by the contracting firms. Literature corroborated these findings, [4] asserted that business does not exist in isolation from the society where it operates, the business entity and host community must have mutually co-exist for productivity and prosperity.

Table 4 indicates result of CSR practices of medium size construction companies executing construction works within the 
Table 2: Respondents Opinions on Availability of CSR Policy in their Organizations

\begin{tabular}{ccc}
\hline Classification & Frequency & Percentage \\
\hline Yes & 11 & 27.5 \\
No & 26 & 65.0 \\
Not Sure & 3 & 7.5 \\
Total & 40 & 100.0 \\
\hline
\end{tabular}

Table 3: Respondents Opinions on Whether CSR is Mentioned as Company Core Mandate

\begin{tabular}{ccc}
\hline Classification & Frequency & Percentage \\
\hline Yes & 7 & 17.5 \\
No & 31 & 77.5 \\
Not sure & 2 & 5.0 \\
Total & 40 & 100.0 \\
\hline
\end{tabular}

Table 4: CRS practices of selected contractors within the study area

\begin{tabular}{|c|c|c|c|}
\hline $\mathrm{S} / \mathrm{N}$ & CSR PRACTICES & $\begin{array}{l}\text { Mean Item } \\
\text { Score(MIS) }\end{array}$ & Rank \\
\hline 1 & $\begin{array}{l}\text { local content policy in } \\
\text { employment for } \\
\text { community indigenes }\end{array}$ & 3.73 & 1 \\
\hline 2 & $\begin{array}{l}\text { sinking of borehole for } \\
\text { community }\end{array}$ & 2.48 & 2 \\
\hline 3 & $\begin{array}{l}\text { cash donation to } \\
\text { community leaders to do } \\
\text { whatever they like in the } \\
\text { community }\end{array}$ & 2.25 & 3 \\
\hline 4 & $\begin{array}{l}\text { provision of scholarship } \\
\text { for indigent students }\end{array}$ & 2.23 & 4 \\
\hline 5 & $\begin{array}{l}\text { construction of } \\
\text { community health centre }\end{array}$ & 2.05 & 5 \\
\hline 6 & $\begin{array}{l}\text { provision of free health } \\
\text { services to community } \\
\text { members }\end{array}$ & 1.98 & 6 \\
\hline 7 & $\begin{array}{l}\text { Construction of } \\
\text { community feeder road }\end{array}$ & 1.90 & 7 \\
\hline 8 & $\begin{array}{l}\text { construction of } \\
\text { community town hall }\end{array}$ & 1.83 & 8 \\
\hline 9 & $\begin{array}{l}\text { construction of } \\
\text { community worship centre }\end{array}$ & 1.65 & 9 \\
\hline 10 & $\begin{array}{l}\text { provision of grants to } \\
\text { deserving community } \\
\text { members }\end{array}$ & 1.53 & 10 \\
\hline 11 & $\begin{array}{l}\text { construction and } \\
\text { renovation of basic } \\
\text { education facilities }\end{array}$ & 1.28 & 11 \\
\hline
\end{tabular}

South-South zone of Nigeria. The result findings indicated that the most important CSR practices in the study area was employment of host community indigenes with $(\mathrm{MIS}=3.73$ ) and ranked 1 st. Other important CSR practices as indicated in the result were sinking of borehole for the community (MIS=2.28) and cash donation to community leaders (MIS=2.25). While construction and renovation of basic education buildings with
(MIS=1.28), provision of grants to deserving community members with (MIS=1.53) and construction of community worship centres with (MIS=1.65) respectively were least ranked. From this result it could be inferred that construction companies executing works in the study area do not really engage in serious CSR practice except incorporating local content policy of community indigenes employment.

The result of the respondents' perceptions on the extent of CRS practices within the study area indicated that CRS practices were low with (MIS =2.43). This result implied that management of medium size construction companies executing works in the South-South zone of Nigeria have not given CSR the required attention it desired. Thus, kidnapping and communal agitation resulting in work stoppage becomes order of the day. Literature findings corroborated this in that [18] contend that registered business entities in Nigeria particularly medium size construction companies do not carry out CSR practices in their host communities.

Table 5 shows the interval at which construction companies engaged in CSR practices within the study area. The findings revealed that $62.5 \%$ of medium size construction companies surveyed engaged in construction works within the area practice CSR on ad-hoc basis. The Table further shows that only $32.5 \%$ and $5.0 \%$ of the construction companies executing works in the area engaged in CSR activities annually and bi-annually respectively. From this result it was clear that the issue of CSR does not occupy pride of place in the heart of management of medium size construction companies executing works in the study area. This is because from the 
result CSR was only undertaken on ad-hoc basis probably to calm frail nerves when need be and not really as a part of business necessity [4]. This finding corroborated the work of [1] that majority construction companies operating within the study areas do not care about economic and social welfares of the host communities.

Table 6 shows the perception of respondents on the frequency of stoppage of construction works due to community agitation or rampage.

Table 5: Interval of CSR Activities in the Study Area

\begin{tabular}{lcc}
\hline Interval & Frequency & Percentage \\
\hline Bi- annually & 2 & 5.0 \\
Annually & 13 & 32.5 \\
Ad-hoc basis & 25 & 62.5 \\
Total & 40 & 100.0 \\
\hline
\end{tabular}

Table 6: Frequency of work stoppage due to Community Agitations

\begin{tabular}{lcc}
\hline Interval & Frequency & Percentage \\
\hline Never & 5 & 12.5 \\
Rarely & 16 & 40.0 \\
Sometimes & 18 & 45.0 \\
Often & 1 & 2.5 \\
Total & 40 & 100.0 \\
\hline
\end{tabular}

Table 7: Frequency of work stoppage due to insecurity

\begin{tabular}{lcc}
\hline Interval & Frequency & Percentage \\
\hline Never & 2 & 5.0 \\
Rarely & 21 & 52.5 \\
sometimes & 16 & 40.0 \\
Often & 1 & 2.5 \\
Total & 40 & 100.0 \\
\hline
\end{tabular}

Table 8: Percentage of profit expended on CSR activities

\begin{tabular}{lcc}
$\begin{array}{c}\% \text { of profit } \\
\text { on }\end{array}$ & & \\
spended & Frequency & Percentage \\
ZSR & 24 & 60.0 \\
\hline $1-10 \%$ & 5 & 12.5 \\
$11-20$ & 11 & 27.5 \\
Not sure & 40 & 100.0 \\
Total & & \\
\hline
\end{tabular}

Table 9: Company experience on key staff kidnapping

\begin{tabular}{lcc}
\hline & Frequency & Percentage \\
\hline Yes & 11 & 27.5 \\
No & 29 & 72.5 \\
Total & 40 & 100.0 \\
\hline
\end{tabular}

The findings revealed that $12.5 \%$ of the respondents indicated that they had never experienced work stoppage due to community agitation/rampage, $40.0 \%$ opined that they rarely experienced work stoppage due to community agitation/ rampage. However, 45.0 $\%$ indicated that there are cases of work stoppage due to community rampage, while only $2.5 \%$ indicated that they often experience work stoppage due to community rampage/agitations. Impliedly, these findings indicated that host communities sometimes react to none adherence to CSR core mandate by the construction companies executing works in the region.

Table 7 shows the perceptions of respondents on the frequency of work stoppage due to insecurity. It was evident from the result that majority $(52.5 \%)$ of the company executing construction works in the region rarely stop construction activities due to insecurity and only $5.0 \%$ of them never stop construction activities as a result of insecurity. However, $40.0 \%$ of the companies executing construction work in the region sometimes stop construction activities on site due to insecurity and only $2.5 \%$ of them often stop construction activities as a result of insecurity on the region. This result therefore implies that medium size construction companies executing construction works in the region often employ other strategies to mitigate against stoppage of construction activities as a result of insecurity, this strategy include engaging the services of security personnel such as the military, police and armed civil defenders; as well as local security personnel licensed to carry arm to guard their sites and key personnel. 
The result of respondents' opinions on enquiry into the percentage of company's profit expended on CSR activities is depicted in Table 8. The result shows that majority $(60.0 \%)$ of medium size construction companies executing works in the study area expend between 1 and $10 \%$ of their profits on CSR activities. On the contrary, only $12.5 \%$ of them expended between 11 and $20 \%$ of their profits on CSR activities. This result indicated that majority of construction companies executing works in the region only expended a meager part of their profits on CSR activities as such majority of communities located along the construction sites do not benefit from the CSR activities of these construction companies. This finding of the study is similar to that of [30] that Julius Berger Nigeria Plc uses greater percentage of its annual profit in servicing shares (as dividends) of its parent company; while less proportion of the profit goes to indigenous shareholders and other numerous stakeholders.

Table 9 shows respondents' perceptions on whether members of key staff of the company have been kidnapped. The result shows that majority $(72.5 \%)$ of medium size construction companies executing construction works in the study area do experience kidnapping of key company's staff. However, only minority $(27.5 \%)$ of medium size construction companies engaged for construction works in the zone have experienced kidnapping of key members of staff at one time or the other. The implication of this result is that though kidnapping is an everyday experience in the South-South region of Nigeria, it does not happen to majority of medium size construction companies.

\section{Test of Hypotheses}

Ho1. There is a relationship between the extent of CSR practice and work stoppage due to community agitation in the study area;

Ho2. There is a relationship between the extent of CSR practice and work stoppage due to insecurity in the study area.

A correlation analysis was carried out to determine whether a relationship exist between CSR practice and work stoppage due to community agitation. The result of the Pearson product-moment correlation coefficient shows that there was a weak, negative correlation between the two variables, $r=-0.014, n=40, p=0.930$, with high extent of CSR practice, there would be lower level of community agitation. The implication of this result to the construction industry is that when contracting companies take the CSR practices more serious, there will be lower rate of community agitations resulting in construction cost and time overruns or in extreme cases project abandonment.

Similarly, the result of Pearson productmoment correlation coefficient was used to explore the relationship between the extent of CSR practice and frequency of work stoppage due to insecurity in the study area. It was found that there was a moderate negative correlation between the two variable, $r=-0.307, p=0.054$, with high extent of CSR practice, there will be lower frequency of work stoppage due to insecurity in the area. The implication of this finding is that some jobless youths in the host communities could be involved in kidnapping of key construction personnel for their selfish interests. Therefore, when construction companies actively involved in CSR practices, the rate of insecurity in the zone will be 
reduced and construction project performance will increase.

\section{Conclusion and Recommendations}

The study appraised the CSR practices of selected medium size contracting companies in South-South zone of Nigeria and concluded that only $27.5 \%$ of the companies executing construction works in the zone have CSR policy in place. It was found that only $17.5 \%$ of studied companies have CSR as core mandate in their company's' vision statement. The most important finding was that construction companies practicing CSR only employed the youths of the host communities as artisans and site workers. The study further reaches conclusion that CSR practices in the study area was low as the MIS rating for extent of CSR practice in the zone was 2.43 on the scale of 5 and that $62.5 \%$ of medium size construction companies engaged in construction works in the area undertake CSR on ad-hoc basis. Thus, CSR practice is not implemented as essential business core value or exigency, but rather as a philanthropic gesture. It was also found that $45.0 \%$ of medium size construction companies executing works in the study area sometimes experienced work stoppage due to community rampage, while majority of the companies rarely stop works due to insecurity. Interestingly, it was found that $60.0 \%$ of studied companies expend only between 1 and $10 \%$ of their profit on CSR activities. It was finally concluded that a weak, negative correlation exists between the extent of CSR practice and frequency of work stoppage on site due to community agitation and a moderate, negative correlation exists between the extent of CSR practice in the region and frequency of work stoppage on site due to insecurity

Stemming from this conclusion, the study recommends an enactment and enforcement of enabling laws that make it compulsory for business owners to have CSR policy and entrench CSR as a core mandate in their vision statement as a criterion for business registration for all categories of construction companies is advocated. Also, there should be a paradigm shift in the business orientation for management of medium size construction companies as research has shown that company that ensure wealth distribution to her host communities tends to maximize profit compare to those that only ensure shareholders' profit maximization. Further studies could employ qualitative research method/approach to investigate the extent of CSR practices among multinational construction companies. A comparative analysis of CSR practices of construction companies in different zones of Nigeria could be embarked on. Also, quantitative appraisal of the relationship between the extent of CSR practices and rate of engagement of construction companies could be under taken.

\section{References}

[1] Oka, N.O. "The Spate of Environmental Degradation and Impacts on Niger Delta Communities' Sustenance", International Journal of Development and Sustainability, Vol. 6, Number 10, 2017, pp 1461-1485.

[2] Francis, P., Lapin, D. and Rossiasco,P. Securing Development and Peace in the Niger Delta: A Social and Conflict Analysis of Change, Woodrow Wilson International Centre for Scholar Africa Programme, Washington, 2011.

[3] Nzekwe, J. U., Oladejo, E. I. and Emoh, F. I. "Project Failure as a Reoccurring Issue in 
Developing Countries: Focus on Anambra State, South East Nigeria", International Journal of Energy and Environmental Research, Vol.3, Number 3, 2015, pp 1-20.

[4] Amaeshi, K. M., Adi, B. C., Ogbechie, C. and Amao, O. O. "Corporate social responsibility in Nigeria: Western mimicry or indigenous practices?" International Centre for Corporate Social Responsibility, Nottingham University Business School, Nottingham, United Kingdom, http://www.nottingham.ac.uk/ business/ICCSR, Accessed on September 25, 2018.

[5] McDermot, P, Giritli, H. and Duman, D.U. "The relationship between corporate social Responsibility and company competitiveness from the perspective of construction industry",

http://www.irbnet.de/daten/iconda/CIB D C27660.pdf, Accessed on April 18, 2018.

[6] Amadi, J.A. and Ndu, E.C. "Corporate social responsibility practice and corporate performance of selected deposit money banks in Nigeria, International Journal of Advanced Studies in Economics and Public Sector Management, Vol.6, Number 1, 2018, pp 63-88.

[7] Andayani, W. and Atmini, S. "Corporate Social Responsibility, Good Corporate Governance, and Firm Performance", Journal of Modern Accounting and Auditing, Vol.10, Number 8, 2012, pp 1484-1495.

[8] Freeman, E. Strategic Management: A Stakebolder Approach, Pitman Boston,1984.

[9] Doane, D. "Beyond Corporation Social Responsibility: Minnows, Mammoths, and Markets, Futures, Vol. 37, 2005, pp 215-229.

[10] Wang, S. Chinese Strategic Decision-Making on CSR, Sustainability, Ethics of Governance: Springer-Verlag, Berlin and Heidelberg, 2015.

[11] Jamali, D. "A Stakeholder Approach to Corporate Social Responsibility: A Fresh Perspective into Theory and Practice", Journal of Business Ethics, Vol.82, Number1, 2008, pp 213-231.

[12] Winch, G.M. Managing Project Stakeholders. In: Morris, P.W.G., Pinto, J.K. (Eds.), The Wiley Guide to Managing Projects, John Wiley \& Sons Inc., New Jersey, 2004.
[13] Yang, J., Shen, Q. and Ho, M. "An Overview of Previous Studies in Stakeholder Management and its Implications for the Construction Industry", Journal of Facilities Management, Vol.7, Number 2, 2009, pp 159175.

[14] Kolk, A. and Pinkse, J. "The Integration of Corporate Governance in Corporate Social Responsibility Disclosures", Corporate Social Responsibility and Environmental Management, Vol. 17, 2010, pp 15-26.

[15] Yang, J, Shen, Q.G., Ho, M., Drew, D.S. and Xue, X. "Stakeholder Management in Construction: An Empirical Study to Address Research Gaps in Previous Studies", International Journal of Project Management, Vol.29, 2011, pp 900-910.

[16] Martinuzzi, A., Kudlax, A., Faber, C. and Wiman, A. CSR Activities and Impacts of the Construction Sector, Sector Profile Based on a Literature Review Developed in the Course of the FP7 Project IMPACT- Impact Measurement and Performance Analysis of CSR, Wien Vienna University of Economics and Business, Austria, 2011.

[17] Waghmare, Y.M., Bhalerao, N. and Wagh, S.V. "Analysis of the Factors Affecting the Stakeholder Management Process in Building Construction Project", International Journal of Innovative Studies in Sciences and Engineering Technology, Vol.2, Number 7, 2016, pp 48-56.

[18] Ekung, S., Ujene, A. and Ebong, U. "Drivers of Corporate Social Responsibility within Construction Organization in Nigeria", International Letters of Social and Humanistic Sciences, Vol. 32, 2014, pp 14-25.

[19] Barde,I. M. and Tela, G. "Corporate social responsibility and financial performance in the Nigerian Construction Industry", In proceedings of International Conference on Humanities, Literature and Management, (ICHLM'15), Dubai: UAE, Jan. 9-10, 2015, pp 88-94.

[20] Carroll, A. B. and Buchholtz, A. K. Business and society: Ethics and stakeholder management (4th ed.), South-Western College Publishing, Cincinnati, $\mathrm{OH}, 2000$.

[21] Bernd, L. W. "Corporate social responsibility communication: Towards a phase model of 
strategic planning": In communicating corporate social responsibility: perspectives and practice, https://doi.org/10.1108/S20439059(2014)0000006022, Accessed on September 25, 2018.

[22] Branco, M.C. and Rodrigues, L.L. "Communication of Corporate Social Responsibility by Portuguese Banks, Corporate Communications: An International Journal, Vol.11, Number 1, 2006, pp 232-248.

[23] Porter, E. M., and Kramer, M. R. "Creating shared value, Harvard Business Review, JanuaryFebruary, 2011, pp 2-17.

[24] Commission of the European Communities. "A Guide to, Communicate About CSR". http://ec.europa.eu/enterprise/policies/sust ainablebusiness/files/csrsme/communicatio

$\underline{\mathrm{n}}$ guide_en.pdf, Accessed on April 18, 2018.

[25] Joyner, B.E, Payne, D. and Raibom, C.E. "Building Values, Business Ethics and Corporate Social Responsibility into the Developing Organizations", Journal of Developing Entrepreneurship, Vol. 7, Number 2, 2002, pp 144-150.

[26] Gray, R., Owen, D. and Lavers, S. Corporate Social Reporting: Accounting and Accountability, Prentice Hall, London, 1987.

[27] Roman L and Grant R. "Corporate Social Responsibility and Tax Aggressiveness: A Test of Legitimacy Theory", Accounting, Auditing \& Accountability Journal, Vol. 26, Number 1, 2012, pp75-100.

[28] Egbe, O. and Parki, O. A. "The Rhetoric of Corporate Social Responsibility in the Niger Delta", ACME: An International Journal of Contemporary Responsibility, Vol.1, Number 3, 2011, pp 123-133.

[29] Tuodolo, F. "Corporate Social Responsibility: Between Civil Society and the Oil Industry in the Developing World. ACME: An International Journal of Contemporary Responsibility, Vol.8, Number 3, 2009, pp 530-541.

[30] Onwuka, K. U. Nature and practice of corporate social responsibility: a study of Julius Berger (Nigeria) plc in Federal Capital Territory, Abuja, (2010-2015). An M.Sc. thesis submitted to school of postgraduate studies, Ahmadu Bello University, Zaria, 2016.

[31] Oke, A. E. and Ogunsemi, D.R. "Competencies of quantity surveyors as value managers in a developing economy". The construction and Building Research Conferences of the Royal Institution of Chattered Surveyor, London, 10-11 September, 2009, 23-38. 